\title{
Respiration quotient variability: bacterial evidence
}

\author{
V. Romero-Kutzner ${ }^{1, *}$, T. T. Packard ${ }^{1}$, E. Berdalet ${ }^{2}$, S. O. Roy $^{3}$, J.-P. Gagné ${ }^{4}$, \\ M. Gómez ${ }^{1}$ \\ ${ }^{1}$ EOMAR, Grupo de Ecofisiología de Organismos Marinos, Universidad de Las Palmas de Gran Canaria 35017, Spain \\ ${ }^{2}$ Institut de Ciències del Mar (CSIC), Passeig Marítim de la Barceloneta, 37-49, 08003 Barcelona, Spain \\ ${ }^{3} 10$ Ryan Court, Embrun, Ontario K0A 1W0, Canada \\ ${ }^{4}$ Université du Québec à Rimouski, Rimouski, Québec G5L 3A1, Canada
}

\begin{abstract}
Respiratory metabolism was compared between 2 different physiological states of acetate- and pyruvate-grown cultures of Pseudomonas nautica and Vibrio natriegens. Here, we analyze $35 \mathrm{~h}$ and $520 \mathrm{~h}$ experiments in which time-courses of protein, pyruvate, acetate, respiratory $\mathrm{CO}_{2}$ production $\left(\mathrm{R}_{\mathrm{CO}_{2}}\right)$, respiratory $\mathrm{O}_{2}$ consumption $\left(\mathrm{R}_{\mathrm{O}_{2}}\right)$, isocitrate dehydrogenase (IDH) activity, and potential respiration $(\Phi)$ were measured. Respiratory quotients (RQs) were calculated as the ratio of the respiration rates $\left(\mathrm{R}_{\mathrm{CO}_{2}} / \mathrm{R}_{\mathrm{O}_{2}}\right)$. Such RQs are widely used in ocean ecosystem models, in calculations of carbon flux, and in evaluations of the ocean's metabolic balance. In all the cultures, the RQ tended to increase. In the case of $P$. nautica on acetate, the RQ rose nearly an order of magnitude from values below 1 during carbon-substrate sufficiency to values close to 10 during carbon-substrate deficiency. In all the cultures, the respiration rates during the growth period paralleled the biomass increase, but after the substrates were exhausted, the respiration rates fell. In contrast, through this same transition period, the IDH activity and the $\Phi$ remained relatively high for the first $10 \mathrm{~h}$ of carbon-substrate deprivation, and then, these enzyme activities fell slowly, along with the biomass, as the carbon-substrate deprivation continued. The nutritional state of the bacteria affected the $R Q$, rendering the $R Q$ variable for physiological and ecological purposes. These results argue that ecosystem models, oceanographic calculations of carbon flux, and evaluations of the ocean's metabolic balance that are influenced by bacterial metabolism need to be reconsidered in light of $R Q$ variability.
\end{abstract}

KEY WORDS: $\mathrm{O}_{2}$ consumption $\cdot \mathrm{CO}_{2}$ production $\cdot$ Isocitrate dehydrogenase $\cdot$ IDH $\cdot$ Electron transport system $\cdot$ ETS $\cdot$ Potential respiration $\cdot$ Growth

\section{INTRODUCTION}

The respiration quotient (RQ), the ratio of the $\mathrm{CO}_{2}$ produced to the $\mathrm{O}_{2}$ consumed in respiration, is an old concept, dating back to the 1860s. Armsby \& Moulton (1925) and Lusk (1928) discuss its use in animal husbandry and human physiology, presenting research of Pettenkofer \& Voit (1866), Warburg (1926), and others who were measuring $R Q$ much earlier. RQ is a dimensionless ratio, calculated mole per mole, and is an index of the type of organic matter being oxidized in respiration. From the shift in RQ from 0.7 to 1.0 , an investigator can differentiate lipid-based biological oxidation (metabolism) from carbohydrate-based metabolism. The majority of studies of respiration in aquatic ecosystems are based on RQ ranging from 0.7 to 1.2 (Berggren et al. 2012), but in many ecological calculations of microbial respiration, an RQ of 1 is assumed (González et al. 2003, Bühring et al. 2006). This practice occurs even though it is known that the $\mathrm{RQ}$ varies from 0.65 to 1.4 in individual ecological microbial communities (del Giorgio et al. 2006). Amado et al. (2013) argue that such an assumption is the only feasible option given the dearth of physio- 
logical studies that document the RQ variability in bacterial respiration and they conclude that more investigations of $R Q$ variability are needed. A recent study of respiration in yeast found an RQ range of 0.4 to 1.4 (Slavov et al. 2014). When an organism is oxidizing carbohydrate, its $\mathrm{CO}_{2}$ production rate and its $\mathrm{O}_{2}$ consumption rate are equal, i.e. the $\mathrm{RQ}=1$. When an organism is oxidizing protein, the RQ is around 0.8, and when oxidizing lipids, it is close to 0.7 (Cantarow \& Schepartz 1967, Guyton 1971, Hoar 1975, Gnaiger 1983, Stanier \& Forsling 1990). When burning organic compounds richer in $\mathrm{O}_{2}$ than carbohydrates, such as carboxylic acids, and when converting carbohydrate to fat, $R Q$ values can be $>1$. When metabolism consumes oxygen-rich oxalic acid $\left(\mathrm{C}_{2} \mathrm{H}_{2} \mathrm{O}_{4}\right)$, RQ can rise to 4 (Dilly 2001). At the other end of the scale, gluconeogenesis (glucose synthesis) occurs when RQ falls below 0.7 (Cantarow \& Schepartz 1967). In this way, RQ variations are generally explained by the fact that the amounts of $\mathrm{CO}_{2}$ and $\mathrm{O}_{2}$ produced are dependent on the oxidation state of the substrate and the pathways by which the substrate is metabolized (Burton 1982, Kader 1987). Berggren et al. (2012) argue from their field studies of Quebec lakes that variability in RQ indicates shifts in bacterial physiology and carbon consumption that cannot be deduced from other measurements. However, in oceanography, only a handful of RQ measurements have been made (Oviatt et al. 1986, Robinson et al. 2002). Nevertheless, when the effort is made to determine the RQ for each situation, as did Obernosterer et al. (2008) in their Southern Ocean iron-fertilization experiment, an $\mathrm{R}_{\mathrm{CO}_{2}}$ production or a carbon oxidation calculation is more accurate.

Whether in the laboratory or in the field, an RQ is essential in calculating either organic carbon consumption or $\mathrm{CO}_{2}$ production from $\mathrm{R}_{\mathrm{O}_{2}}$ consumption measurements (Boucher et al. 1994, Bergström 2011, Giering et al. 2014). In this way, RQ becomes an influential factor in ocean carbon-cycle studies, for calculating carbon flux from plankton metabolism (Packard \& Christensen 2004, Steinberg et al. 2008, Packard \& Gómez 2013, Osma et al. 2014), and in investigating whether the ocean is autotrophic or heterotrophic (Ducklow \& Doney 2013). Here, we measure the RQ in cultures of the marine bacteria Pseudomonas nautica and Vibrio natriegens as they pass from carbon substrate sufficiency to carbon substrate limitation.

$P$. nautica is an oil-degrading bacterium from the Gulf of Fos, France (Bonin et al. 1987a,b), and was used to advance studies of oil-spill bio-remediation (Swannell et al. 1996). V. natriegens is a well-studied non-pathogenic marine bacterium discovered by Payne et al. (1961) in a Georgia salt-marsh (Lee \& Levy 1987, Lee 1995). Carbon-substrate limitation conditions are common in the ocean as marine microbial communities pass from bloom to post-bloom conditions (Liu et al. 2013), and are likely dominant in oligotrophic ecosystems where bacterial respiration accounts for up to $59 \%$ of plankton respiration (Robinson \& Williams 2005). Here, we show that in our cultures, the RQ can range higher than the upper values reported above. To investigate this wide range, we examine time-courses of the physiological respiration rates $\left(\mathrm{R}_{\mathrm{O}_{2}}\right.$ and $\left.\mathrm{R}_{\mathrm{CO}_{2}}\right)$ and the enzymatic activities from the respiratory electron transport system (ETS) and isocitrate dehydrogenase (IDH). ETS and IDH activities are the biochemical enzyme activities that largely control the $\mathrm{R}_{\mathrm{O}_{2}}$ consumption and $\mathrm{R}_{\mathrm{CO}_{2}}$ production (Packard et al. 1996a, Nelson \& Cox 2005, Gnaiger 2009). Via aerobic respiration, marine organisms obtain the energy to live from a wide range of compounds that are reduced in different, but well coordinated biochemical pathways. Two of these key pathways are the Krebs or tricarboxylic acid (TCA) cycle and ETS. IDH is proposed to be a future analytical method for $\mathrm{CO}_{2}$ calculations in the ocean (Packard et al. 1996a, Roy \& Packard 2001), but it needs further investigation, improvement (Robinson \& Williams 2005), and calibration. In our study, we work with 2 substrates: acetate and pyruvate. Acetate, a 2 carbon molecule, is transformed into acetylCoA at the entry of the TCA and, via IDH and alphaketo glutarate dehydrogenase, loses both carbons as $\mathrm{CO}_{2}$ and produces 8 reducing equivalents $\left(\mathrm{e}^{-}\right)$that in turn, lead to the consumption of 2 molecules of $\mathrm{O}_{2}$ $\left(\mathrm{O}_{2}+4 \mathrm{H}^{+}+4 \mathrm{e}^{-} \rightarrow 2 \mathrm{H}_{2} \mathrm{O}\right)$ at cytochrome oxidase in the ETS. Accordingly, the potential RQ for acetate would be 1.0. When pyruvate (a 3-carbon molecule) is cycled through the TCA, it produces 10 reducing equivalents and 3 molecules of $\mathrm{CO}_{2}$ and it consumes $2.5 \mathrm{O}_{2}$ molecules. This would result in an RQ of 1.2. Thus, the use of these different carbon substrates becomes a tool to generate different values of RQ. In $P$. nautica, we found that acetate-grown cultures showed an RQ increase to 10 during carbonlimitation, whereas RQ in pyruvate-grown cultures remained near 1.0 (Roy et al. 1999). However, because of the continued lack of published physiological information about $R Q$, we wanted to investigate this topic with another species and over longer periods of carbon-limitation. We expected that different levels of carbon limitation and different durations of starvation would generate a wider range of RQs. 


\section{MATERIALS AND METHODS}

\section{Experimental design}

To investigate the RQ in different bacterial growth stages, time-course experiments were run on batch cultures at $22^{\circ} \mathrm{C}$, maintained on pyruvate or acetate as described by Berdalet et al. (1995) and Packard et al. (1996b). Short-term experiments were run for a maximum of $35 \mathrm{~h}$, and a (different) set of long-term experiments were run for 2 to $3 \mathrm{wk}$. The bacteria cultures were grown in 25 cotton-plugged $500 \mathrm{ml}$ Erlenmeyer flasks containing $100 \mathrm{ml}$ of media kept slowly rotating on an 'orbital shaker table'. At intervals over the different time courses, 2 flasks were chosen randomly, $25 \mathrm{ml}$ of culture were transferred to the airtight respirometer flasks, and the respiration was measured. Then, samples of the remaining culture in the chosen flasks were taken in duplicate for growth (optical density at $550 \mathrm{~nm}$ [OD550], turbidity measured as absorbance at $550 \mathrm{~nm}$ ), protein, pyruvate, acetate, $\mathrm{R}_{\mathrm{CO}_{2}}, \mathrm{R}_{\mathrm{O}_{2}}$ IDH activity, and potential respiration $(\Phi)$ as the cultures grew exponentially, reached steady state, and passed into senescence.

\section{Bacterial cultures}

Vibrio natriegens (ATCC 33788) and Pseudomonas nautica (Strain 617 from Dr. P. Bonin, Université de la Méditerranée, Marseille, France) were used for these cultures. Before any experiment, the bacteria had been adapted for a minimum of 15 generations to the experimental media (pyruvate or acetate). To inoculate the cultures, a sample from a mother culture in exponential or early stationary phase was used. Cultures were continuously agitated on an orbital shaker at $100 \mathrm{rpm}$ at $22^{\circ} \mathrm{C}$, and growth was followed spectrophotometrically at $550 \mathrm{~nm}$ (OD550). The OD550 had an initial value after inoculation of 0.1 absorbance units.

\section{Culture media}

The general culture procedures have been described by Berdalet et al. (1995) and Roy et al. (1999). More specifically, $P$. nautica was cultured according to the method of Packard et al. (1996a), and the medium for $V$. natriegens was developed from the media of Niven et al. (1977), Baumann \& Baumann (1981), King \& Berman (1984), and Nissen et al. (1987). The optimal conditions for growth of V. na- triegens were experimentally established. They were grown on $400 \mathrm{mM} \mathrm{NaCl}, 10 \mathrm{mM} \mathrm{MgSO}_{4} \cdot 7 \mathrm{H}_{2} \mathrm{O}$, $10 \mathrm{mM} \mathrm{CaCl} 2 \cdot 2 \mathrm{H}_{2} \mathrm{O}, 10 \mathrm{mM} \mathrm{KCl}, 25 \mathrm{mM} \mathrm{NH}_{4} \mathrm{Cl}$, $0.33 \mathrm{mM}$ phosphate buffer, $0.01 \mathrm{mM} \mathrm{FeSO} \cdot 7 \cdot 7 \mathrm{H}_{2} \mathrm{O}$. Initial concentration of the culture-medium carbonsource was $30 \mathrm{mM}$ sodium acetate or $20 \mathrm{mM}$ pyruvate. (Note that these concentrations would provide the same amount of organic carbon at the start of an experiment.) The mean coefficient of variation was $2.1 \%(n=20)$ for acetate and pyruvate. Reagents for the culture media were obtained from Sigma-Aldrich. All components were dissolved in $0.22 \mu \mathrm{m}$ filtered deionized water (except $\mathrm{FeSO}_{4} \cdot 7 \mathrm{H}_{2} \mathrm{O}$ and phosphate buffer), and $\mathrm{pH}$ was adjusted to 7.5 with $1 \mathrm{~N} \mathrm{NaOH}$. To remove particles, the medium was filtered through a GF/F glass fiber filter. Later, the medium was autoclaved for $45 \mathrm{~min}$ at $121^{\circ} \mathrm{C}$. Then, to avoid precipitation during the autoclaving, the phosphate buffer $(0.67 \mathrm{M}, \mathrm{pH} 7.5)$ and the iron sulphate solution $\left(\mathrm{FeSO}_{4}\right.$. $7 \mathrm{H}_{2} \mathrm{O}, 0.1 \mathrm{mM}$ ) were prepared separately. The $\mathrm{PO}_{4}$ buffer was sterilized by autoclaving, and the $\mathrm{FeSO}_{4}$ solution was filtered through $0.22 \mu \mathrm{m}$ acrodiscs. Finally, both solutions were kept frozen and were thawed and added to the culture medium just before use.

\section{Protein measurements}

For every flask, protein samples were taken in duplicate. Five to $10 \mathrm{ml}$ of culture, depending on the level of biomass, were centrifuged at $10000 \times g$ at $4^{\circ} \mathrm{C}$ for 15 min and then frozen in liquid $\mathrm{N}_{2}$ (Ahmed et al. 1976). Later, the bacterial pellets were defrosted, mixed well with 2 to $4 \mathrm{ml} 1 \mathrm{~N} \mathrm{NaOH}$ (at $22^{\circ} \mathrm{C}$ ), and analyzed for protein in aliquots of $0.5 \mathrm{ml}$ by the Lowry method (Lowry et al. 1951) in according with Berdalet et al. (1995). If the absorbance at $750 \mathrm{~nm}$ of the samples exceeded 0.4, the homogenates were diluted and analyzed again. For standardization, duplicate measurements of bovine serum albumin (BSA) from Sigma Chemical Company were used. Their range around the average of these duplicates increased from $2 \%$ during exponential growth to $14 \%$ during stationary phase (after $15 \mathrm{~h}$ ). The mean of these ranges averaged $4.1 \%$.

\section{Biochemical parameters}

For acetate and/or pyruvate and enzyme activity (IDH and ETS), samples were also taken in duplicate from every experimental flask and prepared as for the protein samples (Berdalet et al. 1995). The super- 
natant fluid was collected in an acid-rinsed Corex tube and then stored in liquid $\mathrm{N}_{2}$ for acetate or pyruvate analysis after centrifugation. Samples were thawed and adjusted to $\mathrm{pH} 2$ by adding concentrated phosphoric acid and analyzed by high performance liquid chromatography.

Pellets for IDH extraction were resuspended in $2 \mathrm{ml}$ of buffer at 0 to $4^{\circ} \mathrm{C}$, and activity was determined spectrophotometrically at $340 \mathrm{~nm}$ following the NADPH production (Reeves et al. 1971, 1972, Holms \& Bennett 1971, Berdalet et al. 1995) after $\mathrm{NADP}^{+}$addition. IDH catalyzes the reaction producing $\mathrm{CO}_{2}$ during isocitrate oxidation.

Isocitrate $+\mathrm{NADP}^{+} \leftrightarrow \alpha$-ketoglutarate $+\mathrm{NADPH}+\mathrm{CO}_{2}$

Results are given as $\mu \mathrm{m} \mathrm{CO} \mathrm{Cmin}^{-1}$ per liter of culture. The IDH activity was calculated from the regression line of OD340 versus time. NADPH was used as the standard converting OD340 to $\mathrm{CO}_{2}$ ( $\mu \mathrm{mol})$ because, from the equation above, NADPH production is stoichiometrically equal to $\mathrm{CO}_{2}$ production (1:1). Each data point represented 4 analyses. The mean coefficient of variation was $5.0 \%(\mathrm{n}=20)$.

Samples for ETS were resuspended at 0 to $4^{\circ} \mathrm{C}$ in $2 \mathrm{ml}$ of homogenizing buffer and measured kinetically for ETS activity with a modification of the Packard \& Williams (1981) method as described by Packard \& Christensen (2004). To calculate $\Phi$, ETS in $\mu \mathrm{mol} \mathrm{e}^{-}$ $\min ^{-1} \mathrm{l}^{-1}$ was divided by $4\left(4 \mathrm{e}^{-}+4 \mathrm{H}^{+}+\mathrm{O}_{2} \rightarrow 2 \mathrm{H}_{2} \mathrm{O}\right)$ to give $\mu \mathrm{mol} \mathrm{O}_{2} \mathrm{~min}^{-1} \mathrm{l}^{-1}$ of culture. Again, each data point represents 4 analyses. In the case of ETS, the mean coefficient of variation was $7.2 \%(n=20)$.

\section{Respiration measurements}

$\mathrm{R}_{\mathrm{CO}_{2}}$ and $\mathrm{R}_{\mathrm{O}_{2}}$ were simultaneously measured by a Micro-Oxymax system (Columbus Instruments International). The Micro-Oxymax is a computer-controlled closed-circuit respirometer. The system monitors gas concentrations in the headspace above the culture (www.colinst.com) via 2 well-sealed tubes. The culture itself was sampled by syringe through a septum in each experimental flask. Calculations of incremental and accumulated values for consumption of $\mathrm{O}_{2}$ and production of $\mathrm{CO}_{2}$ were possible because of periodic sensing of the gas concentration. Oxygen measurements were carried out with an oxygen detector based on the principle of a $\mathrm{PbO}_{2}$ fuel cell. $\mathrm{CO}_{2}$ measurements were made with an infrared $\mathrm{CO}_{2}$ detector (sensitive to the $2000 \mu \mathrm{m}$ absorption peak of $\mathrm{CO}_{2}$ ). Both were part of the Micro-Oxymax system. The detection limit was $10 \mathrm{ppm}$ of $\mathrm{O}_{2}$ and
$\mathrm{CO}_{2}$. This is equivalent to $0.44 \mu \mathrm{mol} \mathrm{l^{-1 }}$. The maximum sensitivity for the 2 rates was $8.9 \mathrm{nmol} \mathrm{h}^{-1}$. The instrument had a multiple sample chamber (for up to 20 channels), a reference chamber, and a computerized data acquisition and analysis system. The MicroOxymax maintained aerobic conditions because it periodically refreshed (replenished) the air in the headspace if the $\mathrm{O}_{2}$ level fell below $19.3 \%$ to avoid oxygen limitation. Cultures were maintained at $22^{\circ} \mathrm{C}$ and continuously shaken (to optimize gas exchange). Respiration is given as $\mu \mathrm{mol} \mathrm{O}_{2} \mathrm{~min}^{-1} \mathrm{l}^{-1}$ and $\mu \mathrm{mol}$ $\mathrm{CO}_{2} \mathrm{~min}^{-1} \mathrm{l}^{-1}$. Note that here, $\mathrm{R}_{\mathrm{CO}_{2}}$ refers to $\mathrm{CO}_{2}$ generated by intact bacteria suspended in their growth medium, and $\mathrm{R}_{\mathrm{O}_{2}}$ refers to $\mathrm{O}_{2}$ consumed under the same conditions. A normal measurement took $\sim 30 \mathrm{~min}$. Measurements over $30 \mathrm{~min}$ intervals were referenced against a baseline and a control and were made in duplicate. The calibration of the oxygen detector was done with high-precision gas standards. The respirometry for all the original measurements was described by Berdalet et al. (1995) and Packard et al. (1996b). The mean coefficient of variation was $5.1 \%(\mathrm{n}=20)$ for $\mathrm{R}_{\mathrm{O}_{2}}$ and $5.2 \%(\mathrm{n}=20)$ for $\mathrm{R}_{\mathrm{CO}_{2}}$.

\section{Statistical analysis}

Data were analyzed using the program R (R Development Core Team 2010). Relationships between $\mathrm{R}_{\mathrm{CO}_{2}} / \mathrm{R}_{\mathrm{O}_{2}}$ and IDH/ $\Phi$ over different time scales (shortand long-term experiments) were obtained from the regression equations, using confidence limits of $95 \%$ and Pearson correlation coefficients. ANCOVA was applied to determine statistical differences between slopes and ordinates in the regression lines. Normality of residuals was confirmed using the ShapiroWilks test.

\section{RESULTS}

\section{Data summary}

Two types of experiments were conducted. Shortterm experiments that ran up to $35 \mathrm{~h}$ and long-term ( 2 to $3 \mathrm{wk}$ ) experiments that ran for 330 and $520 \mathrm{~h}$. In all these experiments, we used the 2 bacterial species Pseudomonas nautica and Vibrio natriegens growing on either acetate or pyruvate. In Fig. 1, measurements of substrate (carbon source), protein, enzyme activity (IDH and $\Phi$ ), $\mathrm{R}_{\mathrm{CO}_{2}}$, and $\mathrm{R}_{\mathrm{O}_{2}}$ are shown. Fig. 2 presents comparable long-term experiments in which we made the same measurements. Data for both fig- 

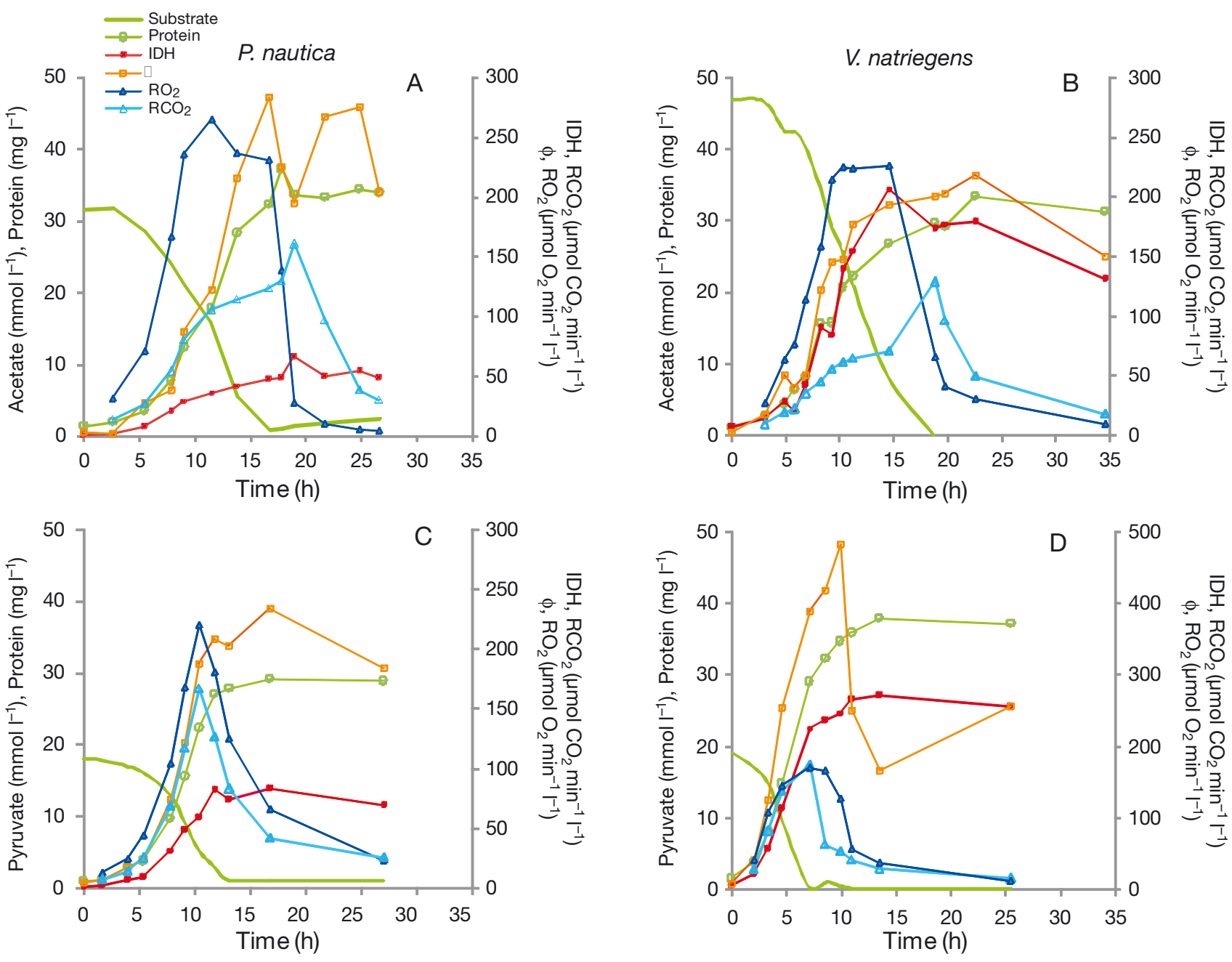

Fig. 1. Short-term experiments. Time courses of respiration, enzyme activity, biomass, and carbon source: (A) Pseudomonas nautica in acetate, (B) Vibrio natriegens in acetate, (C) P. nautica in pyruvate, (D) V. natriegens in pyruvate. Note that, depending on the experiment, the cultures are substrate-sufficient in the first 5 to $15 \mathrm{~h}$ and substrate-limited (starved) afterwards. For display clarity, the protein data have been divided by 10, and $\mathrm{R}_{\mathrm{CO}_{2}}$ and $\mathrm{R}_{\mathrm{O}_{2}}$ have been multiplied by 5 . IDH: isocitrate dehydrogenase; $\phi$ : potential respiration; $\mathrm{R}_{\mathrm{O}_{2}}: \mathrm{O}_{2}$ consumed; $\mathrm{R}_{\mathrm{CO}_{2}}$ : $\mathrm{CO}_{2}$ generated

ures are represented on the same scale so that all the time-courses could be shown in the same graph. However, this required the use of multipliers, as explained in the legends for Figs. 1 \& 2.

\section{Enzyme activity: IDH and $\Phi$}

Short-term experiments. Enzymatic activity is present even during starvation (Fig. 1). In general, the IDH activity and $\Phi$ rise during the hours of substrate sufficiency. After substrate limitation sets in, both parameters in the $P$. nautica cultures stay relatively constant with $\Phi$ higher than IDH. This can be seen when either enzyme activity is normalized by biomass because both the enzyme activities and the biomass trend in parallel with culture age (Fig. 1). During the same conditions of substrate limitation, IDH in the $V$. natriegens cultures retains similarly high activity levels.

Long-term experiments. Enzymatic processes in the long-term experiments (Fig. 2) after $24 \mathrm{~h}$ varied little. In all experiments, enzymatic activity was observable even during carbon substrate limitation. Almost all IDH and $\Phi$ values were similar; IDH ranged from 0.5 to $66 \mu \mathrm{mol} \mathrm{CO} \mathrm{min}^{-1} \mathrm{l}^{-1}$ of culture, while $\Phi$ ranged from 1.3 to $284 \mu \mathrm{mol} \mathrm{O}_{2} \mathrm{~min}^{-1} \mathrm{l}^{-1}$ of culture. In $P$. nautica on acetate (Fig. 2A), IDH rose with carbon substrate limitation and then decreased with $\Phi$ until $\sim 350 \mathrm{~h}$. In $V$. natriegens growing on 

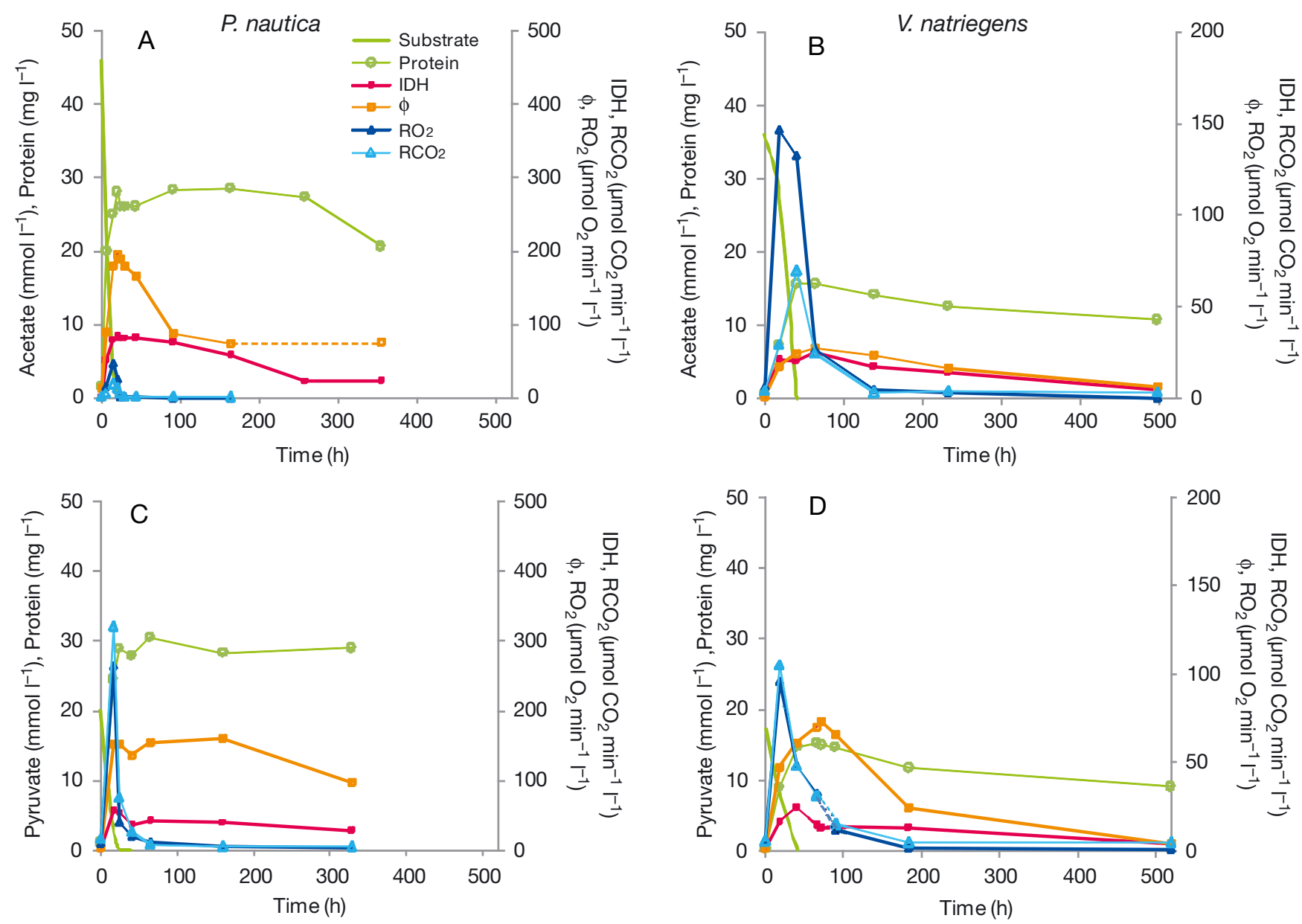

Fig. 2. Long-term experiments. Time courses of respiration, enzyme activity, biomass, and carbon source: (A) Pseudomonas nautica in acetate, (B) Vibrio natriegens in acetate, (C) $P$. nautica in pyruvate, (D) V. natriegens in pyruvate. Note that, except for the first 30 to $35 \mathrm{~h}$, the cultures are continually starved for carbon; they are substrate-limited. During this period, the biomass and the enzyme activities decline, while the respiration $\left(\mathrm{R}_{\mathrm{O}_{2}}\right.$ and $\left.\mathrm{R}_{\mathrm{CO}_{2}}\right)$ is barely measureable. For display clarity, protein data have been divided by 10 , have $\mathrm{R}_{\mathrm{O}_{2}}$ and $\mathrm{R}_{\mathrm{CO}_{2}}$ been multiplied by 10 . Dotted lines symbolize absent data. IDH: isocitrate dehydrogenase; $\phi$ : potential respiration; $\mathrm{R}_{2}: \mathrm{O}_{2}$ consumed; $\mathrm{R}_{\mathrm{CO}_{2}}: \mathrm{CO}_{2}$ generated

acetate, both IDH and $\Phi$ dropped after carbon substrate limitation to levels lower than $4.7 \mu \mathrm{mol} \mathrm{CO}_{2}$ $\min ^{-1} \mathrm{l}^{-1}$ and $6.2 \mu \mathrm{mol} \mathrm{O} \mathrm{Oin}^{-1} \mathrm{l}^{-1}$ (Fig. 2B), respectively. In experiments with $P$. nautica growing on pyruvate, $\Phi$ and IDH remained almost constant for $350 \mathrm{~h}$ after carbon substrate limitation (Fig. 2C). In experiments with $V$. natriegens growing on pyruvate, $\Phi$ maintained activity around $72 \mu \mathrm{mol} \mathrm{O}_{2} \mathrm{~min}^{-1} \mathrm{l}^{-1}$ of culture for the first $100 \mathrm{~h}$ and then decreased to barely detectable levels of activity after $500 \mathrm{~h}$. IDH activities decreased more rapidly in the first $100 \mathrm{~h}$ to $13 \mu \mathrm{mol} \mathrm{CO}_{2} \min ^{-1} \mathrm{l}^{-1}$ of culture and then more slowly in the next $400 \mathrm{~h}$ to $4.5 \mu \mathrm{mol} \mathrm{CO} \mathrm{Cmin}^{-1} \mathrm{l}^{-1}$ of culture (Fig. 2D). Substrate deficiency characterized most of the culture's life. Note that both IDH and $\Phi$ tended to decrease with time as the bacterial cultures starved.

\section{Physiological measurements: $\mathbf{R}_{\mathrm{CO}_{2}}$ and $\mathbf{R}_{\mathrm{O}_{2}}$}

Short-term experiments. In all short-term experiments, $\mathrm{R}_{\mathrm{O}_{2}}$ was higher than $\mathrm{R}_{\mathrm{CO}_{2}}$ before starvation was reached (Fig. 1). Experimental results with $P$. nautica and $V$. natriegens on acetate were similar, but the 2 curves were out of phase. The peaks were displaced in time. In these experiments, $\mathrm{R}_{\mathrm{O}_{2}}$ rose rapidly, but as starvation began, around $15 \mathrm{~h}$, it fell. During this $\mathrm{R}_{\mathrm{O}_{2}}$ fall, $\mathrm{R}_{\mathrm{CO}_{2}}$ peaked and then rapidly declined (Fig. 1A,B). In the 2 pyruvate-based experiments, pyruvate decreased from a initial level of $20 \mathrm{mmol}^{-1}$ to nearly zero after $\sim 10 \mathrm{~h}$ (Fig. 1C,D). In the $P$. nautica culture, both $\mathrm{R}_{\mathrm{CO}_{2}}$ and $\mathrm{R}_{\mathrm{O}_{2}}$ rose and fell in parallel (Fig. 1C). The decrease in respiration occurred before carbon substrate depletion. In the comparable $V$. natriegens pyruvate culture (Fig. 1D), 


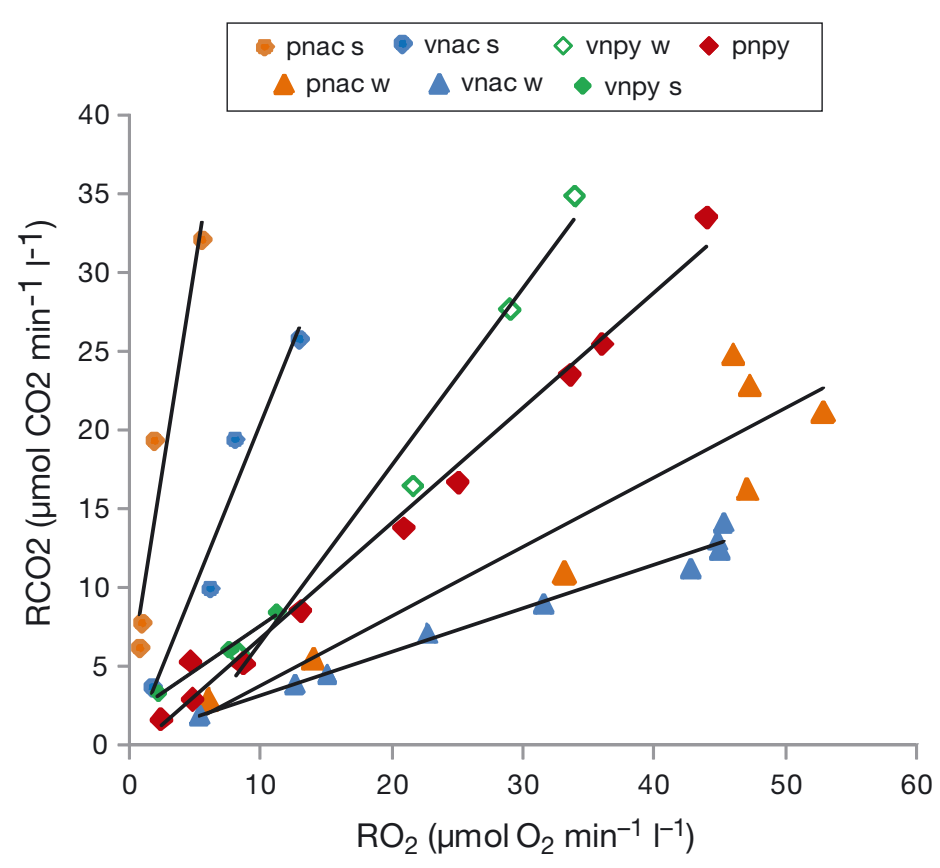

Fig. 3. Short-term experiments. $\mathrm{R}_{\mathrm{CO}_{2}}$ production versus $\mathrm{R}_{\mathrm{O}_{2}}$ consumption; $\mathrm{w}$ is for well-fed (substrate-sufficient), and $\mathrm{s}$ is for starvation conditions (substrate-starved). pnac: Pseudomonas nautica in acetate, pnpy: $P$. nautica in pyruvate, vnac: Vibrio natriegens in acetate, vnpy: $V$. natriegens in pyruvate. For pnpy, the well-fed and starved conditions had the same slope

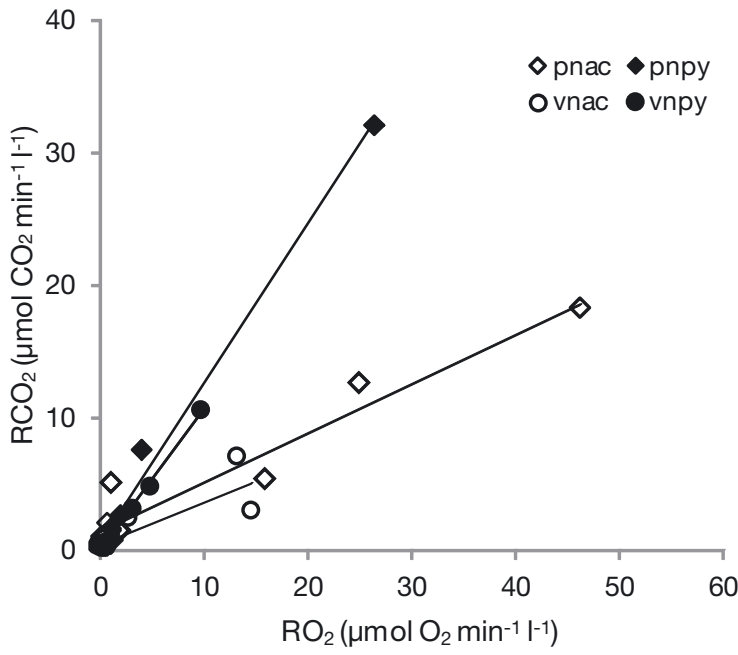

Fig. 4. Long-term experiments. $\mathrm{R}_{\mathrm{CO}_{2}}$ production versus $\mathrm{R}_{\mathrm{O}_{2}}$ consumption with regression equations that include all data points. pnac: $\mathrm{R}_{\mathrm{CO}_{2}}=0.3681 \mathrm{R}_{\mathrm{O}_{2}}+$ $1.5454 ; \mathrm{r}^{2}=0.93 ; \mathrm{n}=9$; $\mathrm{p}<0.05 ;$ pnpy: $\mathrm{R}_{\mathrm{CO}_{2}}=1.204 \mathrm{R}_{\mathrm{O}_{2}}$ $+0.3718 ; \mathrm{r}^{2}=0.99 ; \mathrm{n}=7 ; \mathrm{p}<0.05 ;$ vnac: $\mathrm{R}_{\mathrm{CO}_{2}}=0.3103$ $\mathrm{R}_{\mathrm{O}_{2}}+0.5962 ; \mathrm{r}^{2}=0.65 ; \mathrm{n}=6 ; \mathrm{p}=0.05 ;$ vnpy: $\mathrm{R}_{\mathrm{CO}_{2}}=$ $1.0624 \mathrm{R}_{\mathrm{O}_{2}}+0.0701 ; \mathrm{r}^{2}=0.99 ; \mathrm{n}=7 ; \mathrm{p}<0.05$. Note that the carbon sources dictate the parallelism of the curves, not the bacterial species. In addition, note that the respiration quotient (slope) is higher for the 3-C substrate (pyruvate) than for the 2-C substrate (acetate). This difference cannot be seen in the shortterm experiments (Fig. 3) the respiration signals were out of phase; however, in both of the acetatebased cultures, they were even more out of phase.

In comparing the $\mathrm{R}_{\mathrm{CO}_{2}}$ to $\mathrm{R}_{\mathrm{O}_{2}}$ in the short-term experiments (Figs. 1 \& 3), the relationship between $\mathrm{R}_{\mathrm{CO}_{2}}$ and $\mathrm{R}_{\mathrm{O}_{2}}$ differs with each experiment. High variability is clear (Fig. 3). However, note that in the $P$. nautica in pyruvate (pnpy) culture (Figs. 1C \& 3), the data from both the carbon-sufficient and the carbon-limited phases follows the same correlation $\left(\mathrm{R}_{\mathrm{CO}_{2}}=0.7295 \mathrm{R}_{\mathrm{O}_{2}}-0.5969\right.$, $\left.\mathrm{n}=10, \mathrm{r}^{2}=0.9882, \mathrm{p}<0.05\right)$. For all the experiments, if the substrate-starved and the substrate-sufficient data are considered separately, 2 different relationships appear (Fig. 4). From the equations in Table 1, it is clear that the starved acetate-based cultures have different RQs (slopes) than the starved pyruvate-based cultures.

Long-term experiments. $\mathrm{R}_{\mathrm{CO}_{2}}$ and $\mathrm{R}_{\mathrm{O}_{2}}$ decreased to low values within the first $150 \mathrm{~h}$ of the experiment (Fig. 2).
Table 1. Minimum, maximum, and mean respiratory quotient (RQ) from exponential phase (w: well fed) and stationary phase (s: starvation) for shortterm and long-term experiments. (Note that in all experiments, the transition points between the well-fed and starved conditions were excluded). Regression equations correspond to $\mathrm{R}_{\mathrm{CO}_{2}}=\mathrm{mR}_{\mathrm{O}_{2}}+\mathrm{b}$

\begin{tabular}{|c|c|c|c|c|c|c|c|c|}
\hline $\begin{array}{l}\text { Bact- } \\
\text { eria }\end{array}$ & $\begin{array}{l}\text { Cond- } \\
\text { ition }\end{array}$ & MIN. & $\begin{array}{l}\text { RQ } \\
\text { MAX. }\end{array}$ & Mean & $\overline{\mathrm{SD}}$ & $\begin{array}{c}\text { Regression }^{\mathrm{a}} \\
y=\end{array}$ & $\mathrm{r}^{2}$ & $\mathrm{n}$ \\
\hline \multicolumn{9}{|c|}{ Short-term experiments } \\
\hline pnac & $\begin{array}{l}\mathrm{W} \\
\mathrm{S}\end{array}$ & $\begin{array}{l}0.3 \\
5.7\end{array}$ & $\begin{array}{c}0.5 \\
9.59\end{array}$ & $\begin{array}{l}0.4 \\
7.2\end{array}$ & $\begin{array}{l}0.06 \\
1.66\end{array}$ & $\begin{array}{l}0.4054 x-0.4045 \\
5.2962 x+3.4891\end{array}$ & $\begin{array}{l}0.92 \\
0.92\end{array}$ & $\begin{array}{l}6 \\
4\end{array}$ \\
\hline vnac & $\begin{array}{l}\mathrm{w} \\
\mathrm{s}\end{array}$ & $\begin{array}{l}0.3 \\
1.6\end{array}$ & $\begin{array}{l}0.3 \\
2.4\end{array}$ & $\begin{array}{l}0.3 \\
2.0\end{array}$ & $\begin{array}{l}0.02 \\
0.32\end{array}$ & $\begin{array}{l}0.2769 x+0.3332 \\
2.0564 x-0.4225\end{array}$ & $\begin{array}{l}0.98 \\
0.95\end{array}$ & $\begin{array}{l}9 \\
4\end{array}$ \\
\hline pnpy & $\begin{array}{l}\mathrm{w} \\
\mathrm{s}\end{array}$ & $\begin{array}{l}0.6 \\
0.6\end{array}$ & $\begin{array}{l}0.8 \\
1.1\end{array}$ & $\begin{array}{l}0.6 \\
0.9\end{array}$ & $\begin{array}{c}0.07 \\
0.3\end{array}$ & $0.7598 x-1.2327$ & 0.99 & $\begin{array}{l}5 \\
2\end{array}$ \\
\hline vnpy & $\begin{array}{c}\mathrm{w} \\
\mathrm{s}\end{array}$ & $\begin{array}{l}0.7 \\
0.7\end{array}$ & $\begin{array}{l}1.0 \\
1.3\end{array}$ & $\begin{array}{l}0.9 \\
1.0\end{array}$ & $\begin{array}{l}0.16 \\
0.34\end{array}$ & $\begin{array}{r}1.126 x-5.0411 \\
0.5737 x+1.7177\end{array}$ & $\begin{array}{l}0.97 \\
0.99\end{array}$ & $\begin{array}{l}4 \\
3\end{array}$ \\
\hline \multicolumn{9}{|c|}{ Long-term experiments } \\
\hline pnac & $\begin{array}{l}\mathrm{W} \\
\mathrm{S}\end{array}$ & $\begin{array}{l}0.3 \\
2.4\end{array}$ & $\begin{array}{l}0.8 \\
7.8\end{array}$ & $\begin{array}{l}0.5 \\
4.7\end{array}$ & $\begin{array}{l}0.25 \\
2.23\end{array}$ & $\begin{array}{r}0.383 x+0.1797 \\
4.2758 x-0.1633\end{array}$ & $\begin{array}{l}0.99 \\
0.76\end{array}$ & $\begin{array}{l}3 \\
5\end{array}$ \\
\hline vnac & $\begin{array}{l}\mathrm{w} \\
\mathrm{s}\end{array}$ & $\begin{array}{l}0.2 \\
0.6\end{array}$ & $\begin{array}{l}0.7 \\
1.2\end{array}$ & $\begin{array}{l}0.4 \\
0.9\end{array}$ & $\begin{array}{l}0.33 \\
0.29\end{array}$ & $0.928 x-0.0242$ & 0.99 & $\begin{array}{l}2 \\
3\end{array}$ \\
\hline pnpy & $\begin{array}{l}\mathrm{w} \\
\mathrm{s}\end{array}$ & $\begin{array}{l}1.2 \\
0.6\end{array}$ & $\begin{array}{l}1.9 \\
1.2\end{array}$ & $\begin{array}{l}1.6 \\
0.9\end{array}$ & $\begin{array}{l}0.34 \\
0.30\end{array}$ & $\begin{array}{l}1.1533 x+1.5905 \\
0.3266 x+0.3467\end{array}$ & $\begin{array}{l}0.99 \\
0.98\end{array}$ & $\begin{array}{l}3 \\
3\end{array}$ \\
\hline vnpy & $\begin{array}{c}\mathrm{w} \\
\mathrm{s}\end{array}$ & $\begin{array}{l}0.8 \\
1.0\end{array}$ & $\begin{array}{l}1.1 \\
4.5\end{array}$ & $\begin{array}{l}1.0 \\
2.4\end{array}$ & $\begin{array}{l}0.18 \\
1.64\end{array}$ & $0.86 x+0.3836$ & 0.99 & $\begin{array}{l}2 \\
4\end{array}$ \\
\hline
\end{tabular}



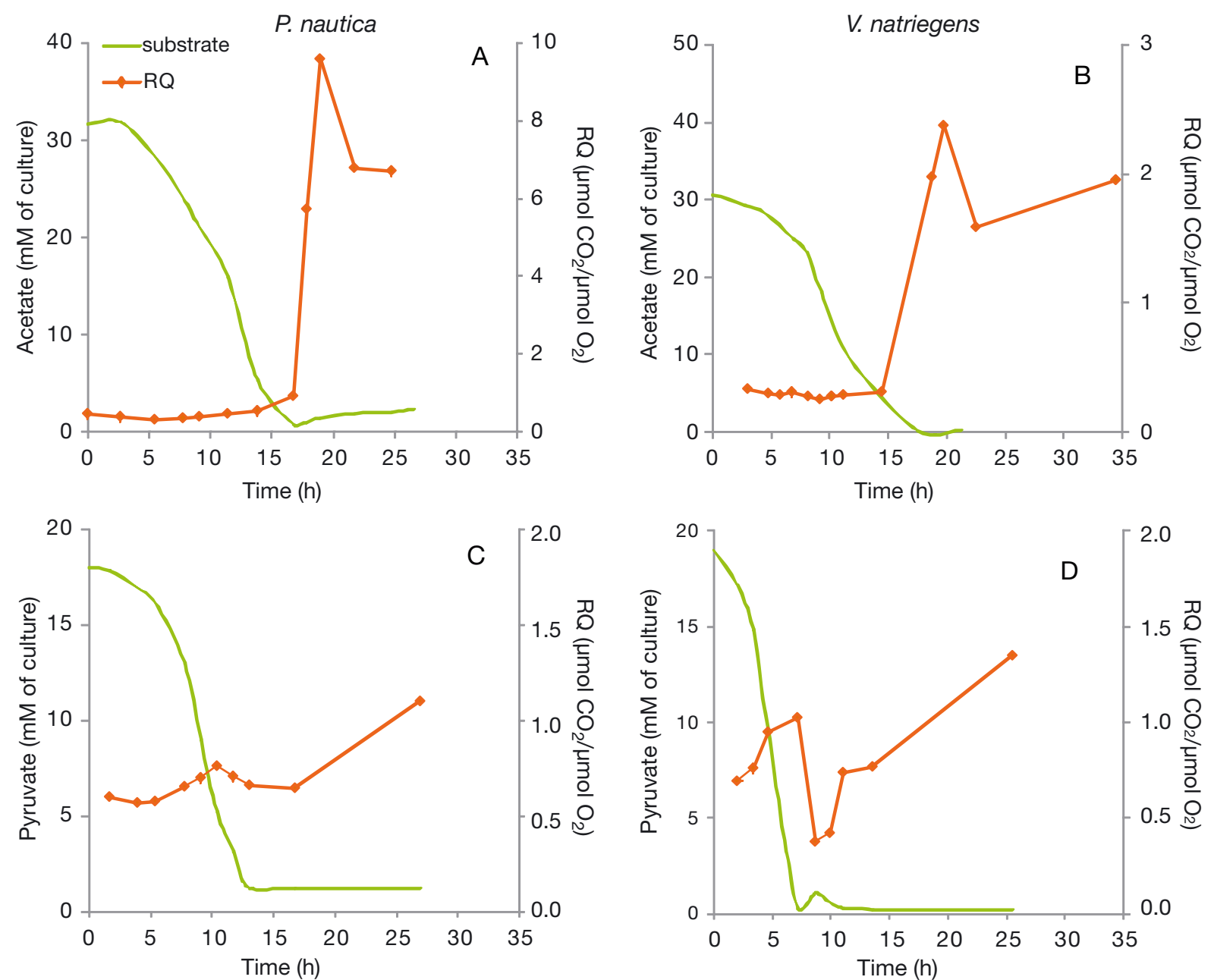

Fig. 5. Short-term experiments: RQ and substrate (carbon source) versus time. Note the carbon substrate sufficiency on the left and carbon substrate depletion (starvation) on the right of each panel. Top panels are acetate-based cultures; bottom panels are pyruvate-based cultures. Left panels are Pseudomonas nautica, right panels are Vibrio natriegens. In all experiments, RQ rises during starvation

After that time, $\mathrm{R}_{\mathrm{CO}_{2}}$ although low, steadily increased in relation to $\mathrm{R}_{\mathrm{O}_{2}}$. This trend contrasted greatly with both the biomass and the enzyme activity data, all of which maintained relatively high values throughout substrate limitation.

All the slopes between the 2 respiration measurements $\left(\mathrm{R}_{\mathrm{CO}_{2}}\right.$ and $\left.\mathrm{R}_{\mathrm{O}_{2}}\right)$ for the long-term experiments were compared (Fig. 4) and displayed a good correlation in all cases except in $V$. natriegens on acetate. The slope of these functions was the overall RQ. This is another way to estimate $R Q$, but requires sufficient samples collected during the same culture condition. ANCOVA analysis between cultures that were growing on the same carbon substrate (i.e. P. nautica or $V$. natriegens on acetate) shows that the slopes were not significantly different (Fig. $4 ; \mathrm{p}>0.05$ ). In contrast, for the same bacterial species but for different substrates (i.e. P. nautica on acetate or pyruvate), the slopes appeared to be significantly different $(\mathrm{p}<$ 0.05). All the slopes (RQs) during starvation conditions were significantly different $(p<0.05)$.

\section{Respiration quotient}

Short-term experiments. RQ measurements in the short-term experiments are shown in Fig. 5. When the cultures were substrate-sufficient, RQs were low, but when carbon substrate limitation started in the acetate cultures of both $P$. nautica and $V$. natriegens, the $R Q$ values rose dramatically (Table 1, Fig. 5A,B). In $P$. nautica on pyruvate, the RQ rose only at the end of the experiment (Fig. 5C). In contrast to the constant pre-starvation $\mathrm{RQ}$ values in the first 3 experiments, in the $V$. natriegens culture growing on pyruvate (Fig. 5D), the signal displayed noticeable noise 

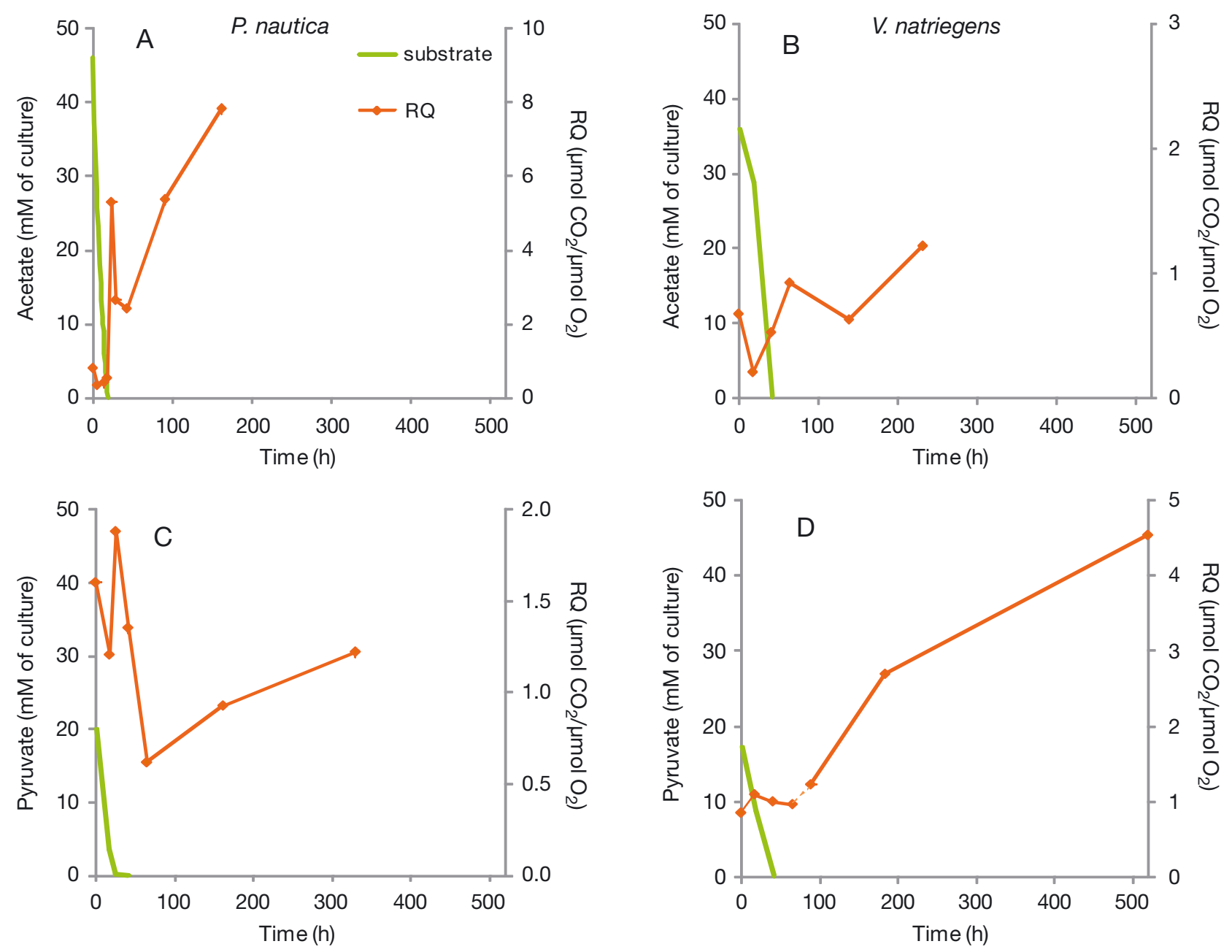

Fig. 6. Long-term experiments: RQ and substrate (carbon source) versus time. Top panels are acetate-based cultures; bottom panels are pyruvate-based cultures. Left panels are Pseudomonas nautica, right panels are Vibrio natriegens. In all panels, RQ increases during the late starvation period

between Hours 7 and 12 of the experiment. Afterwards, at $25 \mathrm{~h}$, it rose to an RQ of 1.4 .

In summary, these short-term experiments show a distinct shift in the RQ when either bacteria species was growing on acetate (Figs. 5A,B). In contrast, when growing on pyruvate, both species displayed an RQ shift, but it was less pronounced than in Figs. 5C,D.

Long-term experiments. The time-course signature of the long-term experiments (Fig. 6) is comparable to that of the short-term experiments (Fig. 5). Of the 4 experiments, $P$. nautica on acetate (Fig. 6A) behaved most similarly to the short-term experiments. In all long-term experiments, carbon substrate limitation began within the first $50 \mathrm{~h}$. We see an RQ jump when carbon substrate limitation was reached, with a subsequent rise to the end of the experiment (Fig. 6A). When $P$. nautica was growing on pyruvate (Fig. 6C) and carbon substrate limitation set in after $65 \mathrm{~h}$, the $\mathrm{RQ}$ rose. However, it rose at a lower rate than in the second experiment ( $V$. natriegens) on pyruvate in which RQ rose to 4.5 at the experiment end (Fig. 6D). In $V$. natriegens growing on acetate (Fig. 6B), RQ rose to 1.2 after acetate exhaustion; however, this RQ was lower than the high value (8.0) found in the $P$. nautica culture growing on acetate (Fig. 6A, Table 1).

\section{DISCUSSION}

\section{RQ and enzyme activity}

RQ shifts can result from the variable activities of different biochemical pathways. In the Krebs cycle, $\mathrm{R}_{\mathrm{CO}_{2}}$ is the collective activity of 3 enzymes: isocitrate dehydrogenase (IDH, EC 1.1.1.42), $\alpha$-ketoglutarate 
dehydrogenase ( $\alpha-\mathrm{KGDH}, \mathrm{EC} 1.2 .7 .3)$, and pyruvate dehydrogenase (PDH, EC 1.2.2.2) (Walsh \& Koshland 1984, Holms 1986a,b). $\mathrm{R}_{\mathrm{O}_{2}}$, although largely controlled by the ETS, is also influenced by all the oxidases, oxygenases, and hydroxylases in a cell. In Figs. 1 \& 2, we see that in starvation, IDH and $\Phi$ activities are still present at relatively high levels, and an IDH dominance is not detectable. Consequently, the RQ elevation (Figs. 5 \& 6) cannot be attributed to the relative activity trends of IDH and ETS. In nature, microorganisms are able to react quickly to environmental changes, adapting their metabolic profiles to organic inputs (Martinez et al. 1996, Mudryk \& Donderski 1997, Sala \& Güde 2004, Mudryk \& Skórczewski 2006). Still, such a mechanism requires time-consuming enzyme induction or activation. Here, the maintenance of IDH and $\Phi$ levels after starvation suggests that Vibrio natriegens and Pseudomonas nautica are prepared to bypass this time-consuming step to be ready to react immediately via Michaelis-Menten kinetics to any fortuitous availability of substrates. Thus, the differential impact of declining substrates $\left(\mathrm{NADP}^{+}\right.$, isocitrate, $\mathrm{NADH}$, and succinate) induced by substrate-limitation could provide the explanation for the declining physiological rates.

\section{RQ variability and carbon limitation}

In this study, we observed a rising RQ after nutrient depletion in cultures of 2 marine bacteria. The RQ ranged from a low of 0.3 during exponential growth to a high of 9.6 during senescence and nutrient depletion (Fig. 5A). In comparison, the RQs in fresh waters of Quebec ranged from 0.25 to 2.26 (Berggren et al. 2012). Those authors argue that the common assumptions of 0.8 to $1.0 \mathrm{RQ}$ values in the literature are not justified. Furthermore, they argue that the use of a constant RQ depresses estimations of the metabolic balance between respiration and photosynthesis, i.e. the $\mathrm{P} / \mathrm{R}$ ratio. They maintain that high RQs have a physiological explanation based on the different biochemical pathways of DOC degradation. However, it is not obvious how RQ could rise to 10 (Fig. 5A) by a biochemical mechanism. This would mean that $\mathrm{O}_{2}$ consumption is severely repressed or that $\mathrm{CO}_{2}$ production is highly stimulated. It is difficult to see how starvation could cause those shifts. Possibly, vegetative cells are being transformed into spores, but what reactions are involved are unknown. Here, the 2 physiological signals of the respiration do appear to shift in the right direction for the $\mathrm{RQ}$ to rise. As starvation sets in, $\mathrm{R}_{\mathrm{O}_{2}}$ decreases before $\mathrm{R}_{\mathrm{CO}_{2}}$ causing the $\mathrm{RQ}$ rise (Fig. $1 \mathrm{~A}, \mathrm{~B}$ ). Why this uncoupling occurs is not obvious. Recent research with nematodes has shown that starvation decreases $\mathrm{R}_{\mathrm{O}_{2}}$ without decreasing the activity of ETS (Chin et al. 2014). This impact was traced to increases in the concentration of alpha-keto glutarate $(\alpha-K G)$, the product of IDH activity. Since $\mathrm{CO}_{2}$ is also a product of IDH activity, perhaps $\mathrm{R}_{\mathrm{CO}_{2}}$ is also stimulated, resulting in a rise in the RQ. Here, we saw the decrease in $\mathrm{R}_{\mathrm{O}_{2}}$ and stability in the ETS but not an increase in the IDH activity and $\mathrm{R}_{\mathrm{CO}_{2}}$. Nevertheless, could starvation have caused an increase in the $\alpha$-KG by another mechanism in our cultures? Additional experimentation is required to address this question.

Another observed trend in our results was that the temporal signatures of the RQs differed between the acetate- and the pyruvate-grown cultures, independent of the species. This difference occurred in short-term experiments but not in the long-term ones (Figs. $5 \& 6$ ). A comparison of the slopes in the $\mathrm{R}_{\mathrm{CO}_{2}}-\mathrm{R}_{\mathrm{O}_{2}}$ regressions (Fig. 4) showed that the biochemistry, not the bacterial species, determined the RQ. An ANCOVA test confirmed it by showing that there was no significant difference in the slopes of $P$. nautica and $V$. natriegens growing on the same substrate (Fig. 4). Because acetate and pyruvate are products of lipid and carbohydrate metabolism, respectively, the short-term experimental results (Table 1) confirmed that carbohydrate consumption leads to higher RQs (0.7 to 1$)$ than does lipid consumption (0.4 to 0.3 ). This is consistent with the historical use of the RQ.

\section{Future research}

In the present study, we document the accompanying $R Q$ changes that occurred in bacterial culture experiments designed to detect the shift in the relationship between respiratory enzyme activity and respiration as exponentially growing bacteria encounter carbon-substrate limitation. The RQ rose after the carbon limitation set in. We had seen this before with short-term experiments of $P$. nautica, but here, this rise is confirmed in long-term experiments with $P$. nautica and with both short-term and longterm experiments with $V$. natriegens. In future experiments, it would be interesting to focus on the shift in $\mathrm{RQ}$ during the opposite transition, from nutrientdepletion (senescence) to carbon-sufficiency, but adding more detailed measurements of the organic components of the culture media. Learning the 
organic composition of the media during the 'nutrient-depletion' phase would be especially interesting. In addition, investigation should be extended to bacteria cultures growing on different substrates; to cultures of phytoplankton, macroalgae, zooplankton, and benthic invertebrates; as well as to natural assemblages of these organisms in field samples. Exploiting mesocosms, as is done in the KOSMOS programs (Riebesell et al. 2013), is an excellent way of achieving the later experiments.

Finally, RQ variability could be used to study biological energy production. At present, RQ is used to differentiate different types of biological oxidation. However, in the future, RQ could also be used as an index of the cost, in terms of organic carbon, of generating a unit of energy (energy production cost). Oxygen consumption is directly related, in aerobic metabolism, to ATP production, and the molar ratio of the ATP production to the reduction of an oxygen atom (ATP/2 $\mathrm{e}^{-}$ratio) (Ferguson 2010) ranges from 2.5 (NADH oxidation) to 1.5 (succinate oxidation). Accordingly, high RQs would indicate that more organic matter is oxidized to produce a unit of ATP than in cases involving low RQs. An inverted RQ $\left[1 / \mathrm{RQ}=\left(\Delta \mathrm{O}_{2}\right.\right.$ consumed $) /\left(\Delta \mathrm{CO}_{2}\right.$ produced $\left.)\right]$ is an index of energy production efficiency. Future research should explore using the RQ to assess both energy production costs and energy production efficiencies.

\section{CONCLUSIONS}

(1) RQ changes with nutritional impact on the physiological state. Bacteria under substrate-limitation have RQs higher than when they are growing under substrate-sufficient conditions.

(2) RQs rise by nearly a factor of 10 (Fig. 5A) during substrate-deficiency (senescence). This suggests that the nutritional conditions of bacteria should be considered, in the future, when selecting an RQ for calculation purposes.

(3) Should this level of RQ variability (Fig. 3) be found in phytoplankton, macroalgae, zooplankton, and benthic invertebrates, then ecosystem models, ocean carbon flux calculations, and predictions of the balance between ocean autotrophy and heterotrophy could be impacted.

(4) Respiration under starved and well-fed conditions of acetate- and pyruvate-based cultures of $P$. nautica and $V$. natriegens show that rates of $\mathrm{O}_{2}$ consumption and $\mathrm{CO}_{2}$ production during substrate-sufficiency parallels the biomass increase (Fig. 1), but that after nutrients are exhausted, both respiration rates fall rapidly. This drop in the respiration rates occurs much sooner and more rapidly than the slow decline in the enzyme activities.

(5) IDH activity and potential respiration (ETS activity expressed in terms of oxygen) can maintain high levels after nutrients are depleted (Figs. 1 \& 2), but after $10 \mathrm{~h}$ of starvation, these values and the cell protein begin to slowly decline as substrate-deficiency persists. The decline in the enzyme activities is much slower after the point of nutrient exhaustion than is the rapid decline in the physiological respiration rates.

Acknowledgements. This work was supported by BIOMBA project CTM 2012-32729/MAR granted to M.G., the University Foundation of Las Palmas by the program 'Innova Canarias 2020' financed by Endesa granted to V.R.-K., and a CIE Canarias tri-Continental Atlantic Campus (\#CEI10/ 00018) contract to T.T.P.

\section{LITERATURE CITED}

Ahmed SI, Kenner RA, King FD (1976) Preservation of enzymatic activity in marine plankton by low-temperature freezing. Mar Chem 4:133-139

Amado AM, Meirelles-Pereira F, Vidal LO, Sarmento H and others (2013) Tropical freshwater ecosystems have lower bacterial growth efficiency than temperate ones. Front Microbiol 4:167

Armsby HP, Moulton CR (1925) The animal as a converter of matter and energy: a study of the role of livestock in food production. Am Chem Soc Monogr Ser, Chemical Catalog Co., New York, NY

Baumann P, Baumann L (1981) The marine Gram-negative Eubacteria: Genus Photobacterium, Beneckea, Alteromonas, Pseudomonas and Alcaligenes. In: Starr S, Trüper HG, Balows A, Schelegel HG (eds) The prokaryotes: a handbook on the biology of bacteria: ecophysiology, isolation, identification, applications. Springer-Verlag, New York, NY, p 1352-1394

Berdalet E, Packard T, Legacé B, Roy S, St-Amand L, Gagné JP (1995) $\mathrm{CO}_{2}$ production, $\mathrm{O}_{2}$ consumption and isocitrate dehydrogenase in the marine bacterium Vibrio natriegens. Aquat Microb Ecol 9:211-217

> Berggren M, Lapierre J, Del Giorgio PA (2012) Magnitude and regulation of bacterioplankton respiratory quotient across freshwater environmental gradients. ISME J 6: 984-993

Bergström I (2011) Carbon gas fluxes from boreal aquatic sediments. Monogr Boreal Environ Res 38

Bonin P, Gilewicz M, Bertrand JC (1987a) Denitrification by a marine bacterium Pseudomonas nautica strain 617. Ann Inst Pasteur Microbiol 138:371-383

Bonin P, Barbotin JN, Dhulster P, Bertrand J (1987b) Nitrate reduction in simulated microniches by a denitrifying marine bacterium. Can J Microbiol 33:276-279

> Boucher G, Clavier J, Garrigue C (1994) Oxygen and carbon dioxide fluxes at the water-sediment interface of a tropical lagoon. Mar Ecol Prog Ser 107:185-193 
Bühring SI, Lampadariou N, Moodley L, Tselepides A, Witte U (2006) Benthic microbial and whole-community responses to different amounts of ${ }^{13} \mathrm{C}$-enriched algae: in situ experiments in the deep Cretan sea (eastern Mediterranean). Limnol Oceanogr 51:157-165

Burton WG (1982) Post-harvest physiology of food crops. Longman, New York, NY

Cantarow A, Schepartz B (1967) Biochemistry, 4th edn. W. B. Saunders, Philadelphia, PA

Chin RM, Fu X, Pai MY, Vergnes L and others (2014) The metabolite $\alpha$-ketoglutarate extends lifespan by inhibiting ATP synthase and TOR. Nature 510:397-401

del Giorgio PA, Pace ML, Fischer D (2006) Relationship of bacterial growth efficiency to spatial variation in bacterial activity in the Hudson River. Aquat Microb Ecol 45: 55-67

> Dilly O (2001) Microbial respiratory quotient during basal metabolism and after glucose amendment in soils and litter. Soil Biol Biochem 33:117-127

$>$ Ducklow HW, Doney SC (2013) What is the metabolic state of the oligotrophic ocean? A debate. Annu Rev Mar Sci 5: 525-533

> Ferguson SJ (2010) ATP synthase: from sequence to ring size to the P/O ratio. Proc Natl Acad Sci USA 107: 16755-16756

Giering SLC, Sanders R, Lampitt RS, Anderson TR and others (2014) Reconciliation of the carbon budget in the ocean's twilight zone. Nature 507:480-483

Gnaiger E (1983) Calculation of energetic and biochemical equivalents of respiratory oxygen consumption. In: Gnaiger E, Forstner H (eds) Polarographic oxygen sensors. Springer-Verlag, Berlin, p 337-345

Gnaiger E (ed) (2009) Mitochondrial pathways and respiratory control, 2nd edn. OROBOROS MiPNet Publications, Innsbruck

> González N, Anadón R, Viesca L (2003) Carbon flux through the microbial community in a temperate sea during summer: role of bacterial metabolism. Aquat Microb Ecol 33: 117-126

Guyton AC (1971) Textbook of medical physiology, 4th edn. W. B. Saunders, Philadelphia, PA

Hoar WS (1975) General and comparative physiology, 2nd edn. Prentice Hall, Upper Saddle River, NJ

Holms WH (1986a) The central metabolic pathways of Escherichia coli: relationship between flux and control at a branch point, efficiency of conversion to biomass, and excretion of acetate. Curr Top Cell Regul 28:69-105

Holms WH (1986b) Evolution of the glyoxylate bypass in Escherichia coli-An hypothesis which suggests an alternative to the Krebs cycle. FEMS Microbiol Lett 34: 123-127

Holms WH, Bennett PM (1971) Regulation of isocitrate dehydrogenase activity in Escherichia coli on adaptation to acetate. J Gen Microbiol 65:57-68

Kader AA (1987) Respiration and gas exchange of vegetables. In: Weichmann J (ed) Postharvest physiology of vegetables. Marcel Dekker, New York, NY, p 25-43

King GM, Berman T (1984) Potential effects of isotopic dilution on apparent respiration in ${ }^{14} \mathrm{C}$ heterotrophy experiments. Mar Ecol Prog Ser 19:175-180

Lee K (1995) Bioremediation studies in low-energy shoreline environments. Proc 2nd Int Oil Spill Res Development Forum. International Maritime Organization, 23-26 May 1995, London

Lee K, Levy EM (1987) Enhanced biodegradation of a light crude oil in sandy beaches. Proc 1987 Oil Spill Conf. American Petroleum Institute, Washington, DC, p 411-416

Liu M, Xiao T, Sun J, Wei H, Wu Y, Zhao Y, Zhang W (2013) Bacterial community structures associated with a natural spring phytoplankton bloom in the Yellow Sea, China. Deep-Sea Res II 97:85-92

Lowry OH, Rosebrough NJ, Farr AL, Randall RJ (1951) Protein measurement with the Folin phenol reagent. J Biol Chem 193:265-275

Lusk G (1928) The elements of the science of nutrition, 4th edn. WB Saunders, Philadelphia, PA

Martinez J, Smith DC, Steward GF, Azam F (1996) Variability in ectohydrolytic enzyme activities of pelagic marine bacteria and its significance for substrate processing in the sea. Aquat Microb Ecol 10:223-230

> Mudryk Z, Donderski W (1997) The occurrence of heterotrophic bacteria decomposing some macromolecular compounds in shallow estuarine lakes. Hydrobiologia 342-343:71-78

Mudryk ZJ, Skórczewski P (2006) Enzymatic activity and degradation of organic macromolecules by neustonic and planktonic bacteria in an estuarine lake. Pol J Ecol 54:3-14

Nelson DL, Cox MM (2005) Lehninger Principles of biochemistry. WH Freeman and Company, New York, NY

Nissen H, Heldal M, Norland S (1987) Growth, elemental composition, and formation of polyphosphate bodies in Vibrio natriegens cultures shifted from phosphate-limited to phosphate-pulsed media. Can J Microbiol 33: 583-588

> Niven DF, Collins PA, Knowles CJ (1977) Adenylate energy charge during batch culture of Beneckea natriegens. J Gen Microbiol 98:95-108

> Obernosterer I, Christaki U, Lefèvre D, Catala P, Van Wambeke F, Lebaron P (2008) Rapid bacterial mineralization of organic carbon produced during a phytoplankton bloom induced by natural iron fertilization in the southern ocean. Deep-Sea Res II 55:777-789

Osma N, Fernández-Urruzola I, Packard TT, Postel L, Gómez M, Pollehne F (2014) Short-term patterns of vertical particle flux in northern Benguela: a comparison between sinking POC and respiratory carbon consumption. J Mar Syst 140(B):150-162

Oviatt CA, Rudnick DT, Keller AA, Sampou PA, Almquist GT (1986) A comparison of system $\left(\mathrm{O}_{2}\right.$ and $\left.\mathrm{CO}_{2}\right)$ and $\mathrm{C}$ 14 measurements of metabolism in estuarine mesocosms. Mar Ecol Prog Ser 28:57-67

Packard TT, Christensen JP (2004) Respiration and vertical carbon flux in the Gulf of Maine water column. J Mar Res 62:93-115

Packard TT, Gómez M (2013) Modeling vertical carbon flux from zooplankton respiration. Prog Oceanogr 110:59-68

Packard TT, Williams PJ LeB (1981) Rates of respiratory oxygen consumption and electron transport in surface seawater from the northwest Atlantic. Oceanol Acta 4: 351-358

> Packard TT, Berdalet E, Blasco D, Roy SO and others (1996a) $\mathrm{CO}_{2}$ production predicted from isocitrate dehydrogenase activity and bisubstrate enzyme kinetics in the marine bacterium Pseudomonas nautica. Aquat Microb Ecol 11: 11-19

Packard TT, Berdalet E, Blasco D, Roy SO and others (1996b) Oxygen consumption in the marine bacterium Pseudomonas nautica predicted from ETS activity and 
bisubstrate enzyme kinetics. J Plankton Res 18: 1819-1835

Payne WJ, Eagon RG, Williams AK (1961) Some observations on the physiology of Pseudomonas natriegens nov. spec. Antonie Leeuwenhoek 27:121-128

Pettenkofer MJ, Voit K (1866) Untersuchungen über den Stoffverbrauch des normalen Menschen. Z Biol 2: 458-573

R Development Core Team (2010) R: a language and environment for statistical computing. R Foundation for Statistical Computing, Vienna. www.r-project.org

Reeves HC, Rabin R, Wegener WS, Ajl SJ (1971) Assays of enzymes of the tricarboxylic acid and glyoxylate cycles. In: Norris JR, Ribbons DW (eds) Methods in microbiology, Vol 6A. Academic Press, New York, NY, p 425-462

Reeves HC, Daumy GO, Lin CC, Houston M (1972) NADP+specific isocitrate dehydrogenase of Escherichia coli. I. Purification and characterization. Biochim Biophys Acta 258:27-39

Riebesell U, Gattuso J, Thingstad TF, Middelburg JJ (2013) Preface: Arctic ocean acidification: pelagic ecosystem and biogeochemical responses during a mesocosm study. Biogeosciences 10:5619-5626

Robinson C, Williams PJ Le B (2005) Respiration and its measurement in surface marine waters. In: del Giorgio PA, Williams PJ le B (eds) Respiration in aquatic ecosystems. Oxford University Press, Oxford, p 147-180

Robinson C, Serret P, Tilstone G, Teira E, Zubkov MV, Rees AP, Woodward EM (2002) Plankton respiration in the Eastern Atlantic Ocean. Deep-Sea Res I 49:787-813

Editorial responsibility: Antonio Bode,

A Coruña, Spain
Roy SO, Packard TT (2001) $\mathrm{CO}_{2}$ production rate predicted from isocitrate dehydrogenase activity, intracellular substrate concentrations and kinetic constants in the marine bacterium Pseudomonas nautica. Mar Biol 138:1251-1258

$>$ Roy SO, Packard TT, Berdalet E, St-Amand L (1999) Impact of acetate, pyruvate, and physiological state on respiration and respiratory quotients in Pseudomonas nautica. Aquat Microb Ecol 17:105-110

Sala MM, Güde H (2004) Ectoenzymatic activities and heterotrophic bacteria decomposing detritus. Arch Hydrobiol 160:289-303

- Slavov N, Budnik BA, Schwab D, Airoldi EM, van Oudenaarden A (2014) Constant growth rate can be supported by decreasing energy flux and increasing aerobic glycolysis. Cell Reports 7:705-714

Stanier M, Forsling M (1990) Physiological processes. McGraw-Hill, London

> Steinberg DK, Van Mooy BAS, Buesseler KO, Boyd PW, Kobari T, Karl DM (2008) Bacterial vs. zooplankton control of sinking particle flux in the ocean's twilight zone. Limnol Oceanogr 53:1327-1338

> Swannell RPJ, Lee K, McDonagh M (1996) Field evaluations of marine oil spill bioremediation. Microbiol Rev 60: 342-365

> Walsh K, Koshland DE Jr (1984) Determination of flux through the branch point of two metabolic cycles. The tricarboxylic acid cycle and the glyoxylate shunt. J Biol Chem 259:9646-9654

Warburg O (1926) Über die Wirkung des Kohlenoxyds auf den Stoffwechsel der Hefe. Biochem Z 177:471-486

Submitted: April 4, 2014; Accepted: October 1, 2014

Proofs received from author(s): December 11, 2014 